\title{
Financial Literacy of Economics and non- Economics Student
}

\author{
Ascaryan Rafinda ${ }^{1,2}$, Timea $\mathrm{Gal}^{2}$ \\ ${ }^{1}$ Faculty of Economics and Business Universitas Jenderal Soedirman, Indonesia \\ ${ }^{2}$ University of Debrecen, Károly Ihrig Doctoral School of Management and Business, Hungary
}

\begin{abstract}
The aim of this research is to identify the level of financial literacy of students in economic faculties and non-economic faculties in Indonesia. This research was conducted to determine the understanding of students in the economic and non-economic faculties on the level of personal financial literacy. The survey was conducted to test the level of student financial literacy in various University in Indonesia. In total there were 206 participants from students in Indonesia who took the survey. An independent sample T-Test was conducted to determine differences in the level of understanding of students in the two groups. The results of this research indicate that there are no differences in the level of financial literacy in economic and non-economic students. This result shows that economics student does not guarantee they have higher personal financial knowledge.
\end{abstract}

\section{INTRODUCTION}

The results of a financial literacy survey of the Indonesian in 2016 explain that the average financial literacy score from Indonesian was only $29.6 \%$ well literated. The capital city of Jakarta has the highest position with $40 \%$ of its population being well literated while the farthest province of West Papua has the lowest literacy rate, only $19.3 \%$ of its population being well literated (OJK), 2017).

Financial knowledge can be obtained from various several sources. The surrounding environment such as family and friends is one of the source ${ }^{*} \mathrm{f}$ financial knowledge (Bowen, 2002; Chen \& Volpe, 2002; Norvilitis \& MacLean, 2010; Shim, Serido, Bosch, \& Tang, 2013; Xiao, Tang, Serido, \& Shim, 2011)). The role of formal financial education also has a contribution to financial maturity and financial behaviour (Alsemgeest, 2015; Norvilitis \& MacLean, 2010; Urban, Schmeiser, Michael Collins, \& Brown, 2018).

Various studies examine the level of financial literacy in tertiary institutions (Anthes, 2004; Godfrey, 2006; Murphy, 2005). Higher education is the highest formal educational institution in Indonesia, the majority of Indonesian people will start working after graduating from higher education institutions. This makes universities the last opportunity to help the community in increasing their financial knowledge (Harrington \& Smith, 2016). 
Because after work, no matter how to literate their financial knowledge, they have to deal with financial issues and decisions.

The issue regarding the low level of financial literacy of Indonesian generally occurs in tertiary institutions. Some research findings identify that students in Indonesia have low levels of financial literacy (Margaretha \& Pambudhi, 2015; Mendari \& Kewal, 2013). Previous studies have identified a positive relationship between financial education in tertiary institutions and the level of one's financial knowledge. The role of universities in increasing financial literacy in Indonesia needs to be explored further. The strategic position of tertiary institutions in improving public financial literacy in Indonesia needs to be identified in current conditions and evaluated for future improvement.

This research identifies the condition of student financial literacy in tertiary institutions to determine the current level of financial literacy in Indonesian tertiary institutions. Universities that have various disciplines in this research will be classified into two groups, namely students from the economic and business group and non-economic and business group. This is to facilitate the identification of gaps between the two of them.

Research that examine the level of student financial literacy in university is important because it can determine the current conditions and the role of universities to improve financial literacy level in Indonesia. This research will explain how the condition of financial literacy in Indonesian universities.

\section{LITERATUR REVIEW}

Various studies have examined the impact of financial education on a person's life. Some interesting research results to study are as follows. Basic financial knowledge education is needed for day-to-day financial management but investment and retirement can be left to professionals (Alsemgeest, 2015). The results of the research found that cognitive aspects in financial education were still lacking to improve one's financial knowledge. There is no one solution for all problems in financial education found (Alsemgeest, 2015).

Some financial literacy research at universities also found the effects of financial education on a financial behaviour. Credit card behaviour was found to be different between students who took financial education and students who did not participate in financial education (Norvilitis et al., 2006).

Students on economics and business at universities get courses related to finance. Although not directly studying management of personal financial, financial courses in general can provide financial perspectives that are quite important in financial decision making. So students in the field of economics and business have a higher understanding of finance than students from non-economics and business. Based on these arguments, the hypothesis proposed in this research is that non-economic and business students have a lower understanding of the level of financial literacy than economics and business students.

\section{RESEARCH METHOD}

The data in this research were taken using a questionnaire. Online and paper based questionnaires were distributed to participants in the form of students in Indonesia. The questionnaire instrument was preceded by informed consent that explained the willingness to participate in this research. Respondents who are willing will proceed to the next question, who are not willing cannot proceed to the next question.

The sample in this research focuses on undergraduate students on several universities in Indonesia. A total of 206 people participated in this research from public and private 
universities in Indonesia. This research takes two months to collect all the data. This research classifies the sample into two groups namely economic and business group and non-economic and business groups. Participants from the economic and business study
Average
$64.95 / 100$ points
Median
$66 / 100$ points
Range
$0-100$ points

Total points distribution

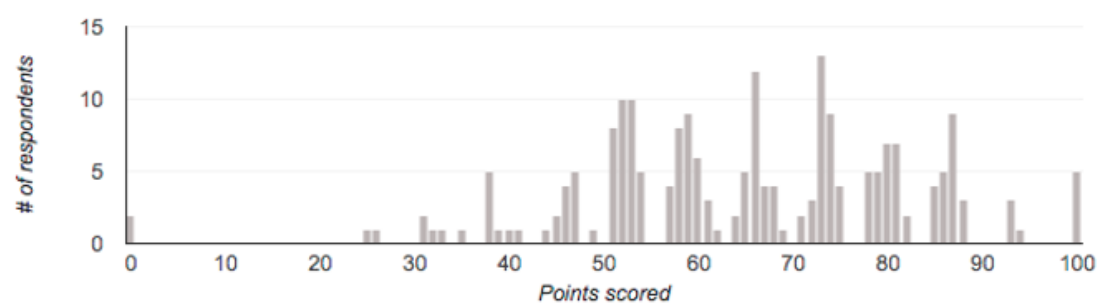

Figure 1 : Statistics Descriptive

group were 87 people and from non-economic and business people 116 people. Here the descriptive statistics from the research sample: From all the research sample, the average financial literacy score is 64,95 . The median is 66 out of 100 points. The maximum score is 100 out of 100 and the lowest is 0 out of 100 points.

Independent sample unequal variance $\mathrm{T}$-Tests are performed to examine the differences test of financial literacy level. Unequal variance t-test was done because the two groups have different variances. The financial literacy instrument measure financial literacy in three areas, namely personal investment, credit transactions and personal financial management. A total of 15 multiple choice questions were given to participants to find out the level of financial literacy. Each participant in this research fills in the instrument within 10-20 minutes depending on the speed of the participants answering the question.

The results of the different tests show that there are statistically significant differences between the two groups. The first group is the non-economic and business group, the second group is the economic and business study group. The first group had an average score of 61.26 , while the second group had an average score of 69.44 . The following is a summary of the results of the statistical tests:

t-Test: Two-Sample Assuming Unequal Variances

\begin{tabular}{lrr}
\hline & First Group & Second Group \\
\hline Mean & 61,26437 & 69,43966 \\
Variance & 176,10372 & 262,66589 \\
Observations & 87,00000 & 116,00000 \\
Hypothesized Mean Difference & 0,00000 & \\
Df & 199,00000 & \\
t Stat & $-3,94774$ & \\
P(T<=t) one-tail & 0,00005 & \\
t Critical one-tail & 1,65255 & \\
P(T<=t) two-tail & 0,00011 & \\
t Critical two-tail & 1,97196 & \\
\hline
\end{tabular}

Hasil Uji Beda T-Test Unequal Variance 


\section{RESULT}

Based on the data taken and tested with statistics, the data shows that the average of the first group was 61.26 and the average of the second group was 69.44 . The results of the unequal variance T-Test show that there are significant differences between the two groups. This significant difference shows that the first group has an average value of financial literacy lower than the average value in the second group.

The first group which is a group of students from non-economic and business programs has an average value of financial literacy lower than the group of students from economic and business programs. Students in the first group have the lowest score of 38 out of a total of 100 points, and the highest score of 85 out of a total of 100 points. Whereas the second group had the lowest score of 45 and the highest score of 100 . In total there were 4 participants who received perfect scores in answering questions in this study.

\section{CONCLUSION}

Students from the economic and business study group have higher financial literacy scores compared to the non-economic and business study group. Although these students do not get formal courses on personal finance, but they have sufficient basic financial knowledge in three fields (investment, credit and personal finance). Optimizing students' personal financial knowledge could be done by giving special courses in the form of personal finance. So students can more specifically understand personal financial management.

This research limits financial literacy to only three areas (investment, credit and personal finance) so it does not measure financial knowledge in other fields. Further research can be optimized by measuring other fields in personal finance to make it more comprehensive.

\section{REFERENCES}

1. Alsemgeest, L. Arguments for and against financial literacy education: Where to go from here? Int. J. Consum. Stud. (2015).

2. Anthes, W. L. Financial illiteracy in America: a perfect storm, a perfect opportunity. J. Financ. Serv. Prof. 58(6), 49 (2004).

3. Faulcon Bowen, C. Financial knowledge of teens and their parents. J. Financ. Couns. Plan. 13(2), 93-102 (2002).

4. Chen, H. \& Volpe, R. Gender Differences in Personal Financial Literacy among College Students. Financ. Serv. Rev. 11(3), 289-307 (2002).

5. Godfrey, N. S. Making Our Students Smart about Money. Education Digest: Essentials Reading Condensed for Quick Review 71(7), 21-26 (2006).

6. Harrington, C. \& Smith, W. College Student Interest in Personal Finance Education. SSRN Electron. J. 25, 351-372 (2016).

7. Kewal Anastasia Sri, S. S. M. Tingkat Literasi Keuangan Di Kalangan Mahasiswa Stie Musi (Financial Literacy Level among Students Stie Musi). J. Econ. 9(2), 130-140 (2013).

8. Margaretha, F. \& Pambudhi, R. A. Tingkat Literasi Keuangan Pada Mahasiswa S1. Tingkat Literasi Keuang. Pada Mhs. S-1 Fak. Ekon. 17(1), 76-85) (2015).

9. Murphy, A. J. Money, Money, Money: An Exploratory Study on the Financial Literacy of Black College Students. College Student Journal, 39(3), 478 (2005). 
10. Norvilitis, J. M., \& MacLean, M. G. The role of parents in college students' financial behaviors and attitudes. J. Eco. Psycho. 31(1), 55-63 (2010).

11. Norvilitis, J.M. et al. Personality Factors, Money Attitudes, Financial Knowledge, and Credit-Card Debit in College Students. J. App. Soc. Pshycho. 36 (6), 13951413 (2006).

12. Shim, S., Serido, J., Bosch, L., \& Tang, C. Financial identity-processing styles among young adults: A longitudinal study of socialization factors and consequences for financial capabilities. J. Cons. Aff. 47(1), 128-152 (2013).

13. Urban, C., Schmeiser, M., Michael Collins, J., \& Brown, A. The effects of high school personal financial education policies on financial behavior. Economics of Education Review (2018).

14. Xiao, J. J., Tang, C., Serido, J., \& Shim, S. Antecedents and Consequences of Risky Credit Behavior Among College Students: Applicatin and Extension of the Theory of Planned Behavior. J. Pub. Pol \& Mark. 30(2), 239-245 (2011). 